\title{
Online Comments as a Tool of Intercultural (Russian-Czech) “Anti-Dialog”
}

\author{
Jiří Gazda \\ Masaryk University
}

\begin{abstract}
This study presents a content and qualitative discourse analysis of readers' comments made on Czech journalism on sociopolitical topics published in Russian translation at InoSMI.ru. Following the tradition of ethnomethodology, which examines the formation of subjective views of the world from the viewpoint of the general population, the interpretation of the examined discourse focuses on analyzing the verbal attitudes of regular Russian readers of political journalism toward the opinions of the Czech public on the current-day Russia and toward Czechs and the Czech Republic in general. Specifically, the study examined the expressions of intolerance toward the opinions of others and linguistic aggression on the part of the Russian-speaking commenters toward the authors of critical Czech journalism as natural and instinctive dismissive reactions to "different" or hostile language and cultural and ideological expressions. The study is based on language data acquired by analyzing readers' comments left on a total of 45 Russian translations of Czech journalistic writings published between January and September 2016 on 12 different Czech websites. The qualitative, critical analysis of the linguistic material is based on a sociocognitive approach, which assumes a dialectical relationship between the discourse and society operating through cognitive structures (knowledge and ideology). The aim of this study was to highlight the negative aspects of unsanctioned public sociopolitical discourse, which is currently made possible and accelerated by technology advances of the Internet network and, at a time of a de facto information war, contributes to the spread of negativistic and hostile attitudes and sentiments, rather than to a genuine intercultural dialog.
\end{abstract}

\section{Keywords}

Czech-Russian relationships; intercultural dialog; language aggression; online comments; sociopolitical discourse

\section{Introduction}

It is hard to miss the raging information war, which reflects the current distribution of political powers in the world and the way they are shifting in their effort to promote various individual, group, national, or international

\footnotetext{
* Jiří Gazda, Masaryk University, Faculty of Arts, Department of Slavonic Studies, 60200 Brno, Arna Nováka 1, Czech Republic; gazda@phil.muni.cz

Text is an output of the grant project GA MU "Russia in the categories friend - enemy. Czech reflection" (code MUNI/M/0921/2015)
} 
economic interests. The Internet has become the main battlefield of these often contradictory interests as well as the space to express one's hostile attitude toward those with different values, cultures, or ideologies (Vargolskaya 2016). At the same time, the situation on this battlefield is quite confused, as every nation has a plethora of news and information websites run by providers who - openly or covertly - protect or promote the opinions and interests of various entities whose intentions and motivations are often unclear.

There can be no doubt that one of the most serious global "information conflicts" is currently the media war between the Euro-Atlantic area, represented primarily by the United States and the EU countries, and Russia. This study did not attempt to provide a political analysis of the causes of this situation, taking it instead as a fact and as the baseline for a sociologically inclined discourse analysis of a specific segment of discourse practice. Specifically, it focused on the ramifications of this state of affairs in the Czech media, on the Russian reaction to Czech media, and on the possible extent to which these events may impact the attitudes of the Russian (and Czech) public and therefore also the Russian-Czech relationship. The study is grounded in the obvious fact that the general "politicization" of public and social life is mirrored in the politicization of public social discourse and that these two phenomena are intertwined.

Public relationships between people, including relationships between members of different ethnic groups, are now highly visible in communications in the mass media, especially online, as the Internet makes it possible to follow the speech behavior of various groups of the participants of communication and their positions in textual form, immediately, and almost without limitations, whether they are the representatives of various institutions (editors of the online portals or authors of the posts and articles themselves), the addressees of the texts, or those who discuss and comment on the texts (Wodak 2008; Orgoňová \& Bohunická 2016).

Thanks to advances in information technology, we live in an era of unlimited opportunities for both direct and indirect global communication transcending all spatial and, in the widest sense of the word, cultural distances. The almost unlimited opportunities for direct or indirect intercultural dialog by presenting and exchanging opinions with immediate as well as open-ended feedback through various discussion forums, chats, unofficial subjective comments to official or semiofficial texts, etc. are among the undisputed benefits of a global and democratic discourse, which takes place primarily through the global Internet. However, there is also a downside to an unrestricted public discourse in the form of unsanctioned presentation of improper, cynical, or 
ethically unacceptable opinions, a rise in verbal aggression and diatribes, and the related spread of hostile attitudes and other negative phenomena, which are not only unsupportive of a genuine intercultural dialog but are also detrimental to it, occasionally to the extent of making such dialog impossible. These are probably the main reasons why linguistic violence and manipulation have ceased to be the exclusive domain of political scientists, sociologists, and psychologists. They have become an increasingly examined topic in linguistics, a science that has the methodological tools for critical text analysis and allows for a better understanding and uncovering of mechanisms of language manipulation to demystify and demythologize social and political discourse (van Dijk 2008; Dubrovskiy 2003; Dzyaloshinskiy 2006; KaraMurza 2000; Petrova \& Ratsiburskaya 2011; Yevstaf'yeva 2009).

The aims of this study were to 1) provide a critical linguistic analysis of Russian readers' comments made on Czech analytic journalism on sociopolitical topics published in Russian translation at InoSMI.ru; 2) analyze the verbal positions of regular Russian readers of political journalism on the opinions of the Czech public regarding contemporary Russia and consequently on Czechs and the Czech Republic in general; 3) identify the main stereotypical motives that serve as the basis for the commenters' arguments and that are characteristic of the current Russian online discourse in relation to the Czech Republic and, in part, to other Central European countries and Slavic nations and the whole of the European Union; 4) map the most frequently used ways of reasoning and linguistic means that are commonly used in the Russian comments to Czech texts and that serve to paint a negative image of Czechs and the Czech Republic for the Russian public.

The study is based on language data acquired by analyzing readers' comments left on a total of 45 Russian translations of Czech journalistic writings published between January and September 2016 on 12 different Czech websites. ${ }^{1}$ Any critical analysis of online comments and discussions in the context of Russian-Czech public sociopolitical discourse needs to take into account its imbalance. The need to take a stand against Russia as a nearby superpower is very obvious in the Czech media environment, while the Russian public usually takes a stand against the United States, Western Europe, or the EU as a whole. The attitude expressed by Russians toward the Czech people and the Czech Republic is mostly neutral, benevolent, or downright dismissive. Among the Slavic nations, Russians show the most negative attitude toward the Poles (for well-known historical reasons).

1 A2larm, Aktuálně.cz, Bez cenzury, Cestomila, Czech Free Press, Echo24.cz, iDnes.cz, Konzervativní listy, Lidovky.cz, Natoaktual.cz, Neviditelný pes, Parlamentní listy.cz 
Another important factor that has a significant impact on the public sociopolitical discourse in the Czech Republic, whether on domestic or foreign matters, is the long-term polarization of the discourse, which goes hand in hand with the polarization of opinions within the Czech Republic. Within the Czech media, the "Russian question" or the attitude toward Russia, its current policy, and its past impact on the development of Czech society is one of the most obvious indicators and a "litmus test" of the views of any given author and the movements that they represent. In this respect, there is an obvious long-term and deepening division of Czech online media that are divided into three groups: openly pro-Russian (and at the same time anti-American and anti-Islamic), basically neutral (but often described as proRussian), and markedly anti-Russian (and at the same time pro-American). However, due to the large number of Czech news portals and their varying readership size, it is very difficult to determine the exact proportion of the abovementioned categories, also because the categorization itself (on the "proRussian- neutral-anti-Russian" scale) is largely dependent on the opinions of the assessor.

The Russian information and news portal "InoSMI.ru" publishes translations of both pro- and anti-Russian journalism. In the sample examined in this study, 16 articles can be assessed as pro-Russian, 26 as anti-Russian, and only two as neutral, based on the prevalent reactions in the Russian comments. The lack of reliable, unbiased, and balanced texts and the overall standard and focus of the texts have a direct impact on the standard of the related discussions and comments. It is the reactions of the Russian readers to the Czech articles that justify viewing the discussion forums at the InoSMI.ru as a means of a Russian-Czech anti-dialog, where one or both participants in the interaction see each other as objects and refuse any solidarity with each other (Korepanova 2007). These reactions can be divided into two general groups, based on the content and focus of the article: negative (ironizing, ridiculing, pejorative, aggressive, or threatening) in the case of anti-Russian or polemical writings and concurring or even laudatory in the case of onesided and uncritical pro-Russian writings. Attempts to judge the journalistic reportage impartially and use factual, sober, and unemotional arguments are very sparse on both sides. Logical argumentation or even positive and selfcritical reactions are an exception and are usually "silenced" very quickly by the other debaters. Oversimplifying and intensifying the (pseudo)arguments, labeling, ridiculing the authors of the text and those with different opinions in the discussion, stereotypical thinking supported by media mainstream, and speech and verbal aggression are typical features of the discussions. 
The readers' comments at InoSMI.ru often perceive the opinions presented by the authors of the articles as the opinions of the majority of Czechs or the official position of the Czech government, which leads to negative and generalizing conclusions about the Czech public. Such - mostly anonymous - discussions are dangerous in that they may inflame negative emotions and excite irrational ethnic intolerance, which is not based on personal experience or deep knowledge, but on intentional or unconscious manipulation of people's minds, similar to deliberate political propaganda.

This study was limited to two aspects of the wider analysis $\left.{ }^{2}: 1\right)$ a partial content analysis of the comments focused on the most frequent types of arguments (negative stereotypes) on the part of those commenting on the Russian translations of Czech writings, showing their opinions and views on the authors of journalism that is critical of modern Russia, on the content of the texts, and on the Czechs and the Czech Republic; and 2) a partial analysis of the most distinct discourse and argumentation strategies used by the commenters to present their own opinions, including descriptions of the linguistic means used to express mostly polemical, highly critical, and dismissive opinions. The analysis of the linguistic material does not concern its relation to specific texts and topics, but the typical argumentation strategies and linguistic means are used to further these strategies, which can be described as general discourse methods and techniques within the given genre of public sociopolitical Russian-Czech discourse on discussion forums. These strategies do not serve as a means of argumentation in a dialog on controversial topics to achieve a better mutual understanding; instead, they are a means of verbal aggression, which, while psychologically understandable, is an ethically unacceptable form of both direct and indirect intercultural communication that can be seen as a refusal to engage in dialog.

The qualitative, critical analysis of the linguistic material is based on a sociocognitive approach (van Dijk 2002), which assumes a dialectical relationship between discourse and society operating through cognitive structures. This approach is characterized by its focus on cognition - the mental representations and cognitive processes that language users rely on to understand and produce discourse - as well as on the social aspects, i.e., the knowledge and ideologies that are shared by different communities and are reflected in discourse (van Dijk 2002, 64). The individual instances of the use of language are motivated by a wish to communicate ideas and convictions or to express emotions, and this use of language then becomes

2 This study is a part of the interdisciplinary research project "Russia in the categories friend - enemy. Czech reflection." 
part of more complex social interactions taking part in specific contexts (van Dijk 1997, 2). At the same time, the social and cognitive aspects of discourse can be understood as the context of the discourse, which this approach views as a part of the cognitive process: in other words, it is not the external environment in which the communication takes place but rather the content of the minds of the individual participants. It is these mental definitions of the situation, meaning they exist only in the minds of those who participate in the communication situation, that govern both the production and the understanding of discourse; van Dijk calls them mental (context) models and they act as intermediaries between the discourse structures and the social structures. With regard to the object of this research, the triangle discourse (a) - cognition (b) - society (c) is represented by a) the comments of Russian readers on the translations of Czech journalism concerning Russia and its global interests; b) group beliefs, shared opinions, and ideologized attitudes of the authors of the comments on the texts; c) Russian-speaking readers of political journalism as representatives of the general Russian public.

The current study focused primarily on those cognitive structures that are reflections of ideology, broadly understood as a socially and ethnically shared set of opinions, attitudes, values, and ideas that serve an apologetic function based on formulating the political or global interests of a certain group and as an axiomatic basis for making judgments that polarize the concepts of "us" and "them," with "us" being the good ones and "them" being the bad ones, just as our ideology excludes them from our group (the ideological square) (van Dijk 2005, 25). Specifically, the study examined the expressions of intolerance toward the opinions of others and linguistic aggression on the part of the Russian-speaking commenters toward the authors of critical Czech journalism as natural and instinctive dismissive reactions to "different" or hostile language, cultural, and ideological expressions. At the same time, the study assumed that, besides the individual identity and the individual world of the values and opinions of every person, there is also a collective identity of a specific cultural environment or community (Richardson \& Colombo 2012, 119-36) that every member of the given community (whether territorial, ethnic, or social) - to a certain degree - identifies with, thus sharing certain collective conventions (stereotypes) that they conform to during certain stages of their collective existence. This assumption makes it possible to select certain collective preferential xenophobic reactions toward members of the Czech ethnic group, which seem to be the most likely ones in the current Russian environment. 
The methodology of the study is based on qualitative research (i.e., research that does not quantify the source language data or use statistical methods), where the researcher is the main research "tool" as he or she monitors the behavior of the participants of communication, tries to understand them, and interprets their behavior correctly (Davis 1995, Lazaraton 2003, van Dijk 1991). Following the tradition of ethnomethodology, which examines the formation of subjective views of the world from the viewpoint of the general population, the interpretation of the examined discourse focuses on analyzing the verbal attitudes of regular Russian readers of political journalism toward the opinions of the Czech public on the current-day Russia and to Czechs and the Czech Republic in general.

The main stereotypical motives that serve as the basis for the commenters' arguments and that are characteristic of the current Russian online discourse in relation to the Czech Republic and, in part, to other Central European countries, Slavic nations and the whole of the European Union are given in the following sections.

\section{Content analysis of the comments at InoSMI.ru}

Content analysis of the comments made on selected Russian translations of Czech writings on sociopolitical topics related to Russia was used to determine the most frequent judgments and arguments, which can be described as negative stereotypes with regard to both the authors of the texts and Czechs and the Czech Republic:

a) Anti-Russian writings are politically motivated, and their authors are paid to write them:

"Horoshaya rabota, tak i nuzhno pisat' pod zakaz."

"Good job! That's how you need to write to order."

"Zakaznaya statejka, $k$ tomu zhe avtor tak hotel obgadit' Rossiyu, chto $v$ dvuh slovah razzheval gejropejskomu obyvatelyu istoriyu kontinenta za bolee chem tysyacheletie."

"A wee little article written to order; moreover, the author wanted to defame Russia so much that, in a couple of words, he recapped more than a thousand years of the continent's history for the Gayropean (gay + Europe) townies."

" $V$ sud, sukiny deti, v sud! Davit' den'gami prodazhnyh zhurnalistov, vadu $i$ prochih zlopyhatelej..."

"To court! Take the sons of bitches to court! Bribing the corrupt journalists, wada (WADA - World Anti-Doping Agency) and other vermin..." 
"Ej-bogu, esli vo vsem mire pressa-prostitutka denezhnyh meshkov, to v Chekhii eto proyavlyaetsya v vysshej stepeni."

"My God - if the press is a corrupt prostitute in the whole world, then Czechia certainly leads the way."

These reactions perpetuate the idea of the Czech media as a tool of antiRussian propaganda directed and funded by the government (or by the US) and of Czech journalists as unprincipled and unprofessional Russophobes, willing to be bribed into publishing lies about Russia. This is proof of the effectiveness of the Russian government propaganda, which distributes this misinformation on a mass scale through official information channels.

b) The authors have limited understanding or are uneducated in history:

"Pohozhe, nekotorye chekhi pozabyli 1968 god. Koe-kto istoriyu ploho uchil."

"It would seem that some Czechs have forgotten 1968. Somebody was skipping their history classes."

"Da. I yshcho, za kazhdogo ubitogo oppozicionnogo chekha, zvyozdochku $v$ petlicu. DB, ne ponyali, kto im mozgi krutil v 68-m?"

"Yes, and also (they used to give) a medal for every anti-regime Czech killed. Idiots, haven't they (Czechs) figured out who was screwing with their heads in '68?'

"Tipichnyj predstavitel' zapadnoj pressy, primitivnoe znakomstvo s istoriej, vidimo s pomoshch'yu komiksov."

"A typical representative of the Western press: very primitive understanding of history, probably based on comics."

"Avtor libo stradaet shizofreniej libo dremuch neimoverno v plane istorii."

"The author is either schizophrenic or he's incredibly illiterate, especially in history."

Interpreting history is one of the most important cognitive dimensions which helps to create the collective and national consciousness of ethnic solidarity and establish feelings of patriotism and national pride. The Russian and the Czech interpretation and assessment of various historical events in which both nations were involved often differ and, in the case of the Prague Spring of 1968 , it is entirely contradictory.

c) The Czechs still find it necessary to take a stand against Russia, while the strong Russian state ignores such attacks by small nations (angry dwarfs):

"Hm... Rossiya ochen' populyarna u chekhov, sudya po aktivnoj diskussii v presse. Chego nel'zya skazat'v protivopolozhnom smysle." 
"Hmm... Based on the lively discussion in the press, Russia seems to be very popular with Czechs. Which can't be said the other way around."

"Ne dayot pokoya Rossiya vsem etim gejropejcam. Prosypayutsya i lozhatsya spat' s dumoj o Rossii."

"Russia doesn't give a moment's peace to all those Gayropeans. Day and night, they keep thinking about Russia."

"Konechno, smeshno, kogda chelovek iz kroshechnoj Chekhii sovetut vsemu russkomu narodu - kak emu zhit'..."

"Obviously, it's ridiculous when someone from teeny-tiny Czechia gives advice to the whole Russian nation on how to live their lives..."

“(...) kogda predstavitel' mikrobnoj evropejskoj strany nachinaet vytaskivat' svoi soobrazheniya o sud'bah rossijskoj ekonomiki, eto vyglyadit kak minimum smeshnym."

“(...) when a representative of a minuscule European country dishes up his ideas on the fate of the Russian economy, it sounds funny to say the very least."

It is typical for Russians to be aware of the size of their own territory and nation and, in connection with this, to be convinced of their own self-sufficiency, autonomy, and superiority over other nations. Therefore, they usually react dismissively to criticism and antagonism by smaller countries and nations.

d) The Czechs have nothing of their own. Everything is owned by foreign powers, and the Czech Republic is under US tutelage:

"Chto takoe Chekhiya? Eto strana, ne imeyushchaya sobstvennoj promyshlennosti, sobstvennoj bankovskoj sistemy, sobstvennyh resursov, sobstvennoj politicheskoj voli. Poetomu prislushivat'sya k lyubym mneniyam chekhov net nikakogo smysla." "What is Czechia? A country with no industry, banking system, resources or political free will. Listening to any opinions of Czechs, therefore, is absolutely useless."

"A po kakomu voprosu mozhno shpionit'v Chekhii? Vsyo, chto bylo cennogo, zahvacheno iudo-anglo-saksami..."

"And what would be the point of spying in Czechia? Anything that had any value has already been taken by the Judeo-Anglo-Saxons..."

“(...) vy prevratilis'v devushku po amerikanskomu vyzovu. Zhivite $v$ kachestve amerikanskoj prislugi, eto vash udel."

“(...) you've become a call girl for the Americans. You live as American servants: that's your lot in life." 
"Vse karlikovye psevdo-strany nahodyatsya pod chuzhim sapogom. (...) A ot vas, chlenov, nichego ne zavisit - vashe delo stroem hodit."

"All tiny pseudo-states live under a foreign yoke. (...) It's not your call, as member countries, to decide anything - keep in step and keep quiet."

A topic which is often reiterated is the lack of autonomy of the Czech Republic and its dependence (and that of the whole of Europe) on the political and economic dictates of the US as the main rival to Russia in power politics.

e) The Czechs lack spine and national pride; they succumb to superpowers as it suits them at the given moment:

"Zapisyvaj, chekh i peredaj drugim chekham: $U$ holopov ne byvaet druzej - u holopov est' tol'ko hozyaeva. Vy stali holopami - prichem dobrovol'no - vot i ostalas' vam kompaniya tol'ko iz takih zhe HOLOPOV."

"Note it down, Czech, and let other Czechs know: servants don't have friends, only masters. You have - voluntarily - become servants, so you only have other SERVANTS for company."

"A tak vy lizali zad nam, potom my proigrali vas amerikancam i teper' vy lizhite zad im. Takaya u vas rabota, lizat' zad sil'nym stranam."

"First, you were brown-nosing us, then we lost you to the Americans, and now you're brown-nosing them. That's your job, brown-nosing strong countries."

"(...) chekhi - lyubiteli lizat' gospodskij (sejchas amerikanskij) sapog..."

"(...) Czechs like to lick their master's (currently the US) boots..."

"Zato sejchas inostrannym soldatam sapogi lizhete. Kak odnako vremya chekhov lechit."

"And now you lick the boots of foreign soldiers. It's extraordinary how Czechs change over time."

Besides the contempt for a weak nation, these types of statements reflect seeing the Czech inclination toward Western values and Euro-Atlantic allies as an unforgivable betrayal of its natural protector, older Slavic brother, and liberator from Nazism.

f) The Czechs are cowards who are unable and unwilling to fight for their country, relying on the help of their powerful "masters" instead:

"V toj vojne, s Gitlerom, u nih sluchilsya odin edinstvennyj geroj, otkryvshij ogon" pri vtorzhenii nemcev. Tak oni ego sami sprovadili v nemeckij konclager."

"In the last war against Hitler, they (the Czechs) had a single hero who opened fire on the invading Germans. So they decided to send him to a German concentration camp." 
“(...) kommentirovat' glupo. Naciya Shvejkov. Otdalis' Gitleru bez edinogo vystrela i vsyu vojnu ispravno klepali emu oruzhie, a potom tak zhe pokorno legli pod SSSR..."

"(...) it's silly to comment on that. A nation of Svejks (a comical soldier character). They surrendered to Hitler without opening fire, spent the whole war diligently making guns for him, and then they surrendered just as meekly to the USSR..."

"Hotyat zhit' bezzabotno i dazhe pal'cem radi svoej bezopasnosti ne poshevelit?" "They (Czechs) would like to live free of worries, not lifting a finger for their own safety?"

"Osobenno chekham ne strashno, kotorye sdali stranu na pervom zhe 'Buuu!' ot nemcev."

"And Czechs especially have no fear - they, who surrendered their own country after the first German 'Boo'!"

From the point of view of a strong, proud, and militarized nation, the Czechs lack of aggression and their willingness to make concessions to enemies is a contemptible and incomprehensible weakness, which further strengthens the feeling of mental superiority in members of the Russian ethnic group.

g) The Czechs have no historical memory and are ungrateful - they forget who liberated them from German fascism:

"Ekh zhalko chto Zhukov bral Pragu bez massirovannoj art podgotovki chto by sohranit' istoricheskij gorod. nado bylo luchshe v poroshok ego steret' pri vzyatii $i$ s ekonomit' zhizni nashih bojcov. sshchas by oni bolee pochtitel'no otnosilis' ibo togda tochno pomnili komu oni obyazany."

"It's a shame that Zhukov seized Prague without any previous massive shellfire to save the historical center of the city. It would have been better to crush it to dust during the attack and save the lives of our soldiers. They (Czechs) would now treat us (Russians) with more respect, as they would know exactly who they owe their thanks to."

"Da ladno uzh, druzhba, blagodarnost'... Pamyatniki ostavili by v pokoe!"

"Ok then, let's forget about friendship or gratitude... If they (Czechs) at least left the monuments (to USSR soldiers) in peace!"

"Napomnite mne, v sleduyushchij raz Chekhiyu ne spasat'?"

"Remind me next time not to save Czechia!"

In general, Russians feel very bitter about the insufficient gratefulness (whether perceived or real) of the Czechs for the liberation from German occupation by Soviet troops, who suffered great losses in the process. The 
objection that any feeling of gratefulness for the liberation was, in most Czechs, neutralized by the Russian military occupation of Czechoslovakia in 1968, is incomprehensible and unacceptable to most Russians due to the Russian imperial mindset.

h) During WWII, the Czechs helped arm Germany against the USSR (or fought on the side of Germany):

"Bol'she vsekh v Evrope s Gitlerom sotrudnichali chekhi - pochti tret' vsekh voenny postavok (tanki, strelkovoe vooruzhenie, artilleriya, motory i t.d.) nemcy poluchili za vsyu vojnu imenno ot chekhov."

"Czechs were Hitler's biggest allies in Europe - the Germans got almost a third of all their military deliveries (tanks, ammunition, artillery, motors, etc.) during the war from the Czechs."

"Chekhi, vot kto dejstvitel'no byl posobnikom i pomoshchnikom Gitlera."

"Czechs, those were the real collaborators and helpers of Hitler."

"Vo vremya 2-j mirovoj chekhi s udovol'stviem shtampovali tanki dlya Vermahta. Posle porazheniya Gitlera oni s upoeniem pisali kak oni borolis's nemeckoj okkupaciej."

"During WWII, the Czechs were happily making tanks for the Wehrmacht. After Hitler's defeat, they started writing elatedly about how they fought against the German occupation."

“(...) pohozhe chekhi pozabyli 41 god kogda v sostave fashistkoj germanii vtorglis' na territoriyu moej strany (SSSR)."

"Czechs seem to have forgotten '41, when they invaded my country (USSR) together with Germany."

The indisputable historical fact that during WWII the Czech arms industry on the territory occupied by the Germans produced weapons for the German Wehrmacht is often misused by Russian commenters for ideological purposes as alleged proof of the treachery and cowardice of the Czech nation as a long-standing enemy of Russia. These assertions deliberately ignore the wider context of the time and the fact that, at the same time, there was an active Czechoslovak resistance network to further polarize the concepts of "us" and "them," even from a historical perspective.

i) The Czechs are hostile Russophobes and traitors to other Slavic nations:

'Chekham nevazhno, komu prisluzhivat', lish' by protiv russkih. Tak bylo vo vremya VOV, kogda oni v pote lica vkalyvali na Gitlera i ego Germaniyu, tak bylo i posle." 
"Czechs don't care who they serve, as long as it's against the Russians. That's how it was during WWII, when they worked hard to help Hitler and his Germany, and that's how it's been since then."

"V Evrope est' tajnoe znanie - rusofobiya, eto klyuch' $k$ vlasti. Chem bol'she ty tyavkaesh' $v$ storonu Rossii, chem sil'nee ty ne navidish' russkih, tem yarche $i$ uspeshnej tvoya politicheskaya kar'era."

"There's a secret principle at work in Europe: being a Russophobe is key to getting to power. The more you bark at Russia, the more you hate Russians, the more dazzling and successful your political career."

"Kto vy chekhi? A nikto! Zhal' vas. Predateli slavyan. Kak i polyaki i bolgary $i$ drugie bratushki."

"Who are you, Czechs? Nobody. I feel sorry for you. Slav traitors, just like the Poles, the Bulgarians and other 'brothers."

"Chekhoslovackaya armiya ni $v$ chem ne ustupala vermahtu. Prosto vzyali $i$ podnyali lapki vverh. Eto ne slovyane."

"The Czechoslovak army was no better than the Wehrmacht. They simply put their paws up (= surrendered). They are no Slavs."

The concepts of Slavism and Slavophilia play an important role in the Russian cognitive structures shaped by culture and history, which form the basis of the idea of Russians and Russia as the hegemon of all (Christian and predominantly Orthodox) Slavic nations as the guarantor of traditional Christian spiritual and cultural values in opposition to the "pseudovalues" of Western civilization. Expressions of hostility toward themselves are then seen as a betrayal of the natural genetic coalition of all Slavic nations led by Russia. A similar analysis of negative Czech comments brings an interesting finding: even though similar stereotypes certainly exist in the relationship of the Czechs to the Russians and Russia, they are almost never explicitly mentioned in the analyzed comments. Any negative views on Russia are rarely based on factual and rational arguments: they are usually emotional and irrational and cannot be generalized into demonstrable and repeated judgmental stereotypes. This stems from the fact that the Czech comments made on the original Russia-related writings often turn into discussions, arguments, and "conflicts" between the debaters. Any black-and-white opinions on the issues on both sides are often challenged, and discussions frequently turn from the presented issue to internal political problems and ideological divides, while Russia and Czech-Russian relationships are sidelined. This seems to show that the participants in these discussions are consciously or unconsciously 
aware that the media spotlight on Russia is overblown and that it is a "red herring" leading attention away from internal unresolved or painful problems.

\section{Analysis of discourse and argumentative strategies of Internet commenters}

The analysis of the most frequent discourse and argumentative strategies used in the comments to the Russian translations of the Czech articles confirms that online comments, primarily those made anonymously, create a culture of aggression and diatribe (vilifying/disparaging), preventing meaningful discussion. Anonymity gives rise to a phenomenon called the online disinhibition effect by the American psychologist John Suler (Suler 2004): a person without identity also loses his or her usual inhibitions. Many studies have also shown that when people know they will not be held accountable for their actions, they are more likely to resort to simplifications and labeling and to be less careful when processing information, which results in oversimplified perception of complex problems (Konnikova 2013).

The categorization of the individual types of linguistic means and discourse strategies is based primarily on the classification by A. P. Skovorodnikov (Skovorodnikov 1997), who presents a detailed classification of functional and semantic types of pejorative manipulative utterances based on negative judgments about specific objects in his study of linguistic violence in the current Russian press. This study focused on the most frequent lexicosemantic techniques and means in argumentation in the Russian comments made on Czech writings that are used to paint a negative picture of the Czechs and the Czech Republic and ultimately obstruct meaningful and constructive intercultural Russian-Czech dialog.

As opposed to the official rhetoric of some pro-Kremlin Russian media, which only use inappropriate reasoning with regard to the Czech Republic and the Czech media, the participants in informal discussions also make extensive use of inappropriate language as part of their devaluing communication strategy, especially expressive vocabulary denoting negative judgments.

a) Utterances that are directly intended to slander or vilify a certain object, in this case, the author or content of the text. To achieve this end, debaters use expressive rude or vulgar terms and idioms or paraphrase them. Besides direct use of diatribes, these types of utterances also use sarcasm and irony for the same purpose:

"Neblagodarnaya svin'ya, etot chekh."

"This Czech guy is such an ungrateful swine." 
"To, o chem pishet etot merzkij chekh (...) Putin i Medvedev provodyat v zhizn'." "What this nasty Czech writes about (...) is put into practice by Putin and Medvedev."

"U etogo cheloveka siflis mozga."

"This person suffers from syphilis of the brain."

"Ocherednaya cheshskaya gadina otkryla svoyu smerdyashchuyu past."

"Another Czech serpent has opened his stinking mouth."

Extreme examples of such utterances contain verbalized threats of physical violence (whether meant seriously or as a hyperbole):

"Popadetsya avtor - stuknu po golove etogo dyatla."

"If I could get my hands on the scribbler, I'd give him a smack on the head."

"(...) Zdenek, v prilichnom obshchestve za takoe - mordu b'yut..."

“(...) Zdeněk (first name of the author of the article), this is something that'd earn you a punch in the face in polite society..."

“(...) a ya bemu propisala za otkrovennoe neprikrytoe razzhiganie mezhnacional'noj rozni. I ne s pomoshch'yu zakona, a tryapkoj po mordochke."

“(...) I'd give him as much as he can take for openly instigating intolerance between nations. And I don't mean via the law, but via a punch in the face."

"Rano ili pozdno my pridem v vashu Chekhiyu a ravno i v Evropu i reshim vashu sud'bu tak kak nam eto zablagorassuditsya! (...) Uzhe zavtra my vas sozhrem $i$ spustim v unitaz kak musor, ibo vremya rabotaet na nas i na nashi cennosti!"

"Sooner or later, we'll come to your Czechia and to Europe and we'll decide about your fate however we see fit! (...) Tomorrow, we'll swallow you up and flush you down the drains like rubbish, because time works for us and our values!"

b) Utterances that paint a negative picture through demonizing and labeling. Sometimes they "determinologize" political expressions by substituting propagandistic and judgmental ideologemes for precisely defined terms. At other times, artificially created negative expressions serve the same function:

"Chekhi kak krymskie turki. Posobniki nacistov. Nado ih denacificirovat' $i$ vyslat'..."

"The Czechs are like the Crimean Turks. Nazi collaborators. They need to be denazified and sent away..."

"Nu a sejchas chekhov okkupirovali pindosy. Iz ognya da v polymya!" 
"Well, and now the Czechs are occupied by Pindoses (derogatory term for Americans). Out of the frying pan into the fire."

"Chekhi luchshe pust' zajmutsya svoej ekonomikoj, podpindosoviki."

"Those Pindose-serving Czechs should rather take care of their own economy."

"Vot ono, istinnoe lico presmykayushchejsya gejropy, upadi samolet pendo-rejha, traur by ustroili. Ne o chem nam s nimi razgovarivat'."

"This is the true face of the wicked Gayrope; if a Pindo-Reich (USA) plane crashed, they would be in national mourning. We have nothing to talk about with them."

c) Utterances that vilify the opponent or ideological adversary through clusters of substandard lexicon, colloquial expressions, argot, standard lexicon expressing negative judgments, and expressive metaphors:

" $V$ kazhdoj nacii est' gnusnye moral'nye urody, kotorym greyut serdce vsyacheskie merzozsti, gadosti i prochie fobii. Petr Nejedly tipichnyj predstavitel' gnusov rusofobov pravil'no sdelali, chto vydvorili ego iz strany..."

"In every country there are nasty, morally despicable freaks who warm their hearts with various nasty and filthy stuff and other phobias. Petr Nejedlý is a typical representative of nasty Russophobes and it's a good thing they turned him out of the country."

"Avtor - tvar' redkostnaya. Podobnoj merzosti pro Rossiyu i russkij narod ya na INOSMI, navernoe, eshchyo ne chital."

"The author is an extraordinary jerk. I don't think I've read anything so atrocious about Russia and the Russian people at INOSMI yet."

"Ocherednaya rusofobskaya gryaz' iz vostochno-evropejskogo zverinca."

"Another Russophobic scumbag from the East-European menagerie."

“(..) pochemu takie ushiblennye otmorozki raz"ezzhayut po moej Rodine $i$ pozvolyayut sebe oskorbitel'no-nekompetentnye vyskazyvaniya? Pochemu takim vrazhinam voobshche dayut vizy?!"

"(...) why are such raving lunatics coming to my homeland and daring to make such offensive and incompetent comments? Why do they even give visas to such hateful jerks?”

d) Ironizing and ridiculing; putting the object in an ironic context. Irony is a covert form of manipulation, as it is not always directly obvious (lexicosemantic opposites, parody, or antithesis). In most cases, irony is not used to support one's arguments, but substitutes them. It is also often accompanied and sometimes replaced by sarcasm: 
"Vsya stat'ya - rassuzhdeniya karlika o velikane. Obychnaya evropejskaya vosh'." "The whole article is the musings of a dwarf about a giant. A common European louse."

"Kollega, ne prinimajte blizko k serdcu. Eto zhe chekh... on dumaet chto on ochen' umnyj, Bog emu sud'ya."

"Don't take it to heart, mate. Why, he's a Czech... and he thinks he's clever, God bless him."

"Eto zamechatel'no, chto Chekhiej pravyat vot takie ublyudki."

"It's amazing that Czechia is ruled by such bastards."

"Mozhet Chekhii samoj podelitsya popolam mezhdu Rossiej i Germaniej. Ya obeshchayu, chto k gornechnoj iz Chekhii ya budu otnosit'sya horosho ne unizhaya ee velichiya."

"Maybe Czechia could divide itself between Russia and Germany. I promise that in that case, I'll treat the Czech chambermaid respectfully, as befits her majesty."

e) Assertion, i.e., a pragmatic textual method whereby the speaker uses an implied presupposition that contains a discrediting notion (judgment) about a specific object:

"Pohozhe, nekotorye chekhi pozabyli 1968 god. Koe-kto istoriyu ploho uchil. Ili zahoteli vstretit' cvetami konvoj kakih-nibud' chushek tipa Babaya?"

"It would seem that some Czechs have forgotten 1968. Somebody was skipping their history classes. Or perhaps they'd like to throw flowers on a convoy of assholes like Babay?"

"Edinstvennaya cennost' chekhov - eto ih demokratiya, no voevat' za neyo ochen' strashno da i nekomu, tem bolee, chto pobedy dazhe gipoteticheski ne vidat."

"Democracy is the only value that Czechs have, but they are very much afraid to fight for it - all the more because even hypothetical victory is not in sight." "U kazhdogo svoya istoriya. Chekhiya grustit ob osvobozhdenii ee iz-pod Gitlera. Pol'sha voyuet s pamyatnikami. Rossiya vspominaet po ubitym geroyam."

"Everybody's got their own history. Czechia is sorry for having been liberated from Hitler. Poland is at war with its monuments. Russia remembers its fallen heroes."

"Chekhoslovakiya - eto takaya strana, kotoraya vsegda byla gotova votknut' nozh $v$ spinu SSSR, i Rossii. Poetomu prizhat' eyo k nogtyu v sluchae neobhodimostivo imya mira, eto opravdano." 
"Czechoslovakia is a country that's always been ready to backstab USSR and Russia. That's why taking it by the throat is perfectly justifiable - in the name of peace."

f) Unsubstantiated generalization (lack of arguments). In the texts examined in this study, opinions on the authors are usually generalized to the whole ethnic group:

"Tak tochno, u nas prakticheski v kazhdoj sem'e est' predok geroj! A nemnogie eshchyo zhivy - nizkij im poklon! Chekham ne ponyat'..."

"Exactly, in our country (Russia) there are heroes among the ancestors of practically every family! And some of them are still alive - deepest respect to them! Czechs can't understand that..."

"Ran'she dogadyvalsya, chto u chekhov problema s logicheskim myshleniem. Teper' ubedilsya."

"I have previously suspected that Czechs struggle with logical thinking. Now I'm certain."

"Kak strashno zhit' chitaya chekhov pered zavtrakom!"

"How dreadful it is to live when you have to read (texts by) Czechs before breakfast!"

“'Eto dejstvitel'no my, chekhi?' Konechno zhe eto Vy $i$ Vashe nastoyashchee lico.... Radovat'sya goryu drugih u Vas v krovi."

" 'Is this really us, Czechs?' Of course it's you and your true face. Delighting in other people's misfortunes is in your DNA."

\section{Conclusion}

The suggested concepts of perceiving the Czech Republic and Czechs more or less fall into the category of "negative discourse" (van Dijk 1991) and express - mostly negative - views of part of the Russian public toward Czechs and the Czech Republic as a part of the EU. These are based on the critical opinions of the Czech public (as mediated by Czech journalists) on the current-day Russian society and official foreign policy and lead to a strengthening of heterostereotypes about the Czech ethnic group as a nation mostly hostile to Russia and characterized by intense Russophobia, ungratefulness, and disloyalty to Russia as a former ally and liberator from Nazism, opportunism, cowardice, and the absence of patriotism and the ethos of Slavic solidarity. The cognitive dimension of this specific intercultural discourse is characterized by a polarized conceptual dichotomy of "us" and "them," where the mental selfrepresentation of the Russian ethnic group (us) is based on the implicit idea 
of Russia as a strong and fearless imperial power and its historical mission as the protector of traditional spiritual, moral, and cultural values, while the concept of "them" expresses an idea of the Czech ethnic group as a nation representing, in a concentrated form, all the abovementioned "anti-values" of the current Western civilization, which is hostile to Russia.

Negative discourse strategies that serve to create the image of the enemy are, within the examined discourse, based primarily on direct defamation of those with an opposing opinion (including verbalized threats of physical violence), their demonizing, labeling, and denigration through substandard lexicon and expressive metaphors, ironizing, and ridiculing, or through assertion and unsubstantiated generalization.

The long-term systematic study of this specific type of online discourse, in which Czechs and Russians express their opinions about the other ethnic group (whether based on their own personal experience or received insights), shows that the expressed attitudes of the participants on both sides are currently mostly negative or at best restrained or indifferent. Even though this can be a halo effect (judging a whole by its parts), caused by the abovementioned circumstances, it is a phenomenon that has, in general, more in common with "anti-dialog" than genuine intercultural dialog. Many participants in these discussions are not really debaters but mere commenters, who are not trying to exchange views and opinions to find out the real state of things but rather to spread a priori negativistic and hostile attitudes and sentiments. Even though the questions listed earlier are a sociological and psychological challenge rather than a linguistic one, they are closely related to broadly defined aspects of philology and pedagogy, language culture education, genuine intercultural communication, and learning about other cultures, histories, languages, nationalities, and individuals as a basic educational prerequisite to remove interethnic and intercultural barriers.

\section{Sources}

A2larm. http://inosmi.ru/a2larm_cz/

Aktuálnè.cz. http://inosmi.ru/aktualne_centrum_cz/

Bez cenzury. http://inosmi.ru/bez-cenzury_com/

Cestomila. http://inosmi.ru/cestomila_cz/

Czech Free Press. http://inosmi.ru/czechfreepress_cz/

Echo24.cz. http://inosmi.ru/echo24_cz/

iDnes.cz. http://inosmi.ru/idnes_cz/

Konzervativni listy. http://inosmi.ru/konzervativnilisty_cz/

Lidovky.cz. http://inosmi.ru/lidovky_cz/ 
Jiří Gazda, Online Comments as a Tool of Intercultural (Russian-Czech) “Anti-Dialog”

Natoaktual.cz. http://inosmi.ru/natoaktual_cz/

Neviditelný pes. http://inosmi.ru/neviditelnypes_zpravy_cz/

Parlamentni listy.cz. http://inosmi.ru/_parlamentni_listy/

\section{References}

Davis, Kathryn A. 1995. "Qualitative Theory and Methods in Applied Linguistics Research." TESOL Quarterly 29 (3): 427-53.

Dubrovskiy, Dmitriy, and Oksana Karpenko. 2003. Yazyk vrazhdy v russkoyazychnom Internete: materialy issledovaniya po opoznavaniyu tekstov nenavisti. [The Language of Hatred in the Russian-Speaking Internet: Study on Recognition of Texts of Hate]. Sankt-Peterburg: Izdatelstvo Evropeyskogo Universiteta v Sankt-Peterburge.

Dzyaloshinskiy, Iosif. 2006. Yazyk vrazhdy v rossiyskikh SMI: sotsialnyye, kulturnyye, professionalnyye faktory. [The Language of Hatred in the Russian Media: Social, Cultural, Professional Factors]. Moscow: Gumanitarnyy Institut.

Kara-Murza, Sergey. 2000. Manipulyatsiya soznaniyem. [Manipulation with Consciousness]. Moscow: Algoritm.

Konnikova, Maria. 2013. “The Psychology of Online Comments.” The New Yorker. October 23. http://www.newyorker.com/tech/elements/the-psychology-of-online-comments.

Korepanova, Elena. 2007. "Psikhologicheskiye kharakteristiki dialoga v pedagogicheskoy deyatelnosti." [Psychological Characteristics of Dialogue in Pedagogical Activities]. Vestnik TGU 3 (47): 152.

Lazaraton, Anne. 2003. "Evaluative Criteria for Qualitative Research in Applied Linguistics: Whose Criteria and Whose Research?” The Modern Language Journal 87 (1): 1-12.

Orgoňová, Olga, and Alena Bohunická. 2016. "Imigrácia ako predmet xenoslovakistiky a kritickej analýzy diskurzu na Slovensku." [Immigration as a Subject of Xenoslovak Studies and of Critical Discourse Analysis in Slovakia]. Jazyk a politika. Na pomedzi lingvistiky a politológie [Language and Politics. Between Linguistics and Political Science], edited by Radoslav Štefančík, 79-93. Bratislava: EKONÓM.

Petrova, Nataliya, and Larisa Ratsiburskaya. 2011. Yazyk sovremennykh SMI: sredstva rechevoy agressii. [The Language of Modern Media: Means of Verbal Aggression]. Moscow: Flinta, Nauka.

Richardson, John E., and Monica Colombo. 2012. "National Identity and Insecurity in AntiImmigrant Discourse: An Analysis of the Visual Propaganda of the Front National." In Le discours et la langue: Revue de linguistique française et d'analyse du discours 3 (1): 119-36.

Skovorodnikov, Aleksandr. 1997. "Yazykovoye nasiliye v sovremennoy rossiyskoy presse. [Linguistic Violence in Contemporary Russian Print Media].” In Teoreticheskiye i prikladnyye aspekty rechevogo obshcheniya: nauchno-metodicheskiy byulleten, Vyp. 2. [Theoretical and Applied Aspects of Verbal Communication: scientific-methodical bulletin, Vol. 2], edited by Aleksandr Skovorodnikov, 10-15. Krasnoyarsk: Krasnoyarskiy gosudarstvennyy universitet.

Suler, John. 2004. “The Online Disinhibition Effect." Cyberpsychology and Behaviour 7 (3): 321-6. 
Van Dijk, Teun A. 1991. “The Interdisciplinary Study of News as Discourse.” In A Handbook of Qualitative Methodologies for Mass Communication Research, edited by Klaus Bruhn Jensen and Nicholas W. Jankowski, 108-20. London: Routledge.

Van Dijk, Teun A., ed. 1997. Discourse as Structure and Process (Discourse Studies: A Multidisciplinary Introduction, 1). London: Sage.

Van Dijk, Teun A. 2002. "Critical Discourse Studies: A Sociocognitive Approach.” In Methods of Critical Discourse Analysis, edited by Ruth Wodak and Michael Meyer, 95-120. London: Sage.

Van Dijk, Teun A. 2005. "Opinions and Ideologies in the Press." In Approaches to Media Discourse, edited by Allan Bell and Peter Garret, 21-63. Oxford: Blackwell Publishing.

Van Dijk, Teun A. 2008. Discourse and Power. Contributions to Critical Discourse Studies. Houndmills: Palgrave MacMillan.

Vargolskaya, Virdzhiniya. 2016. "Razgovor napryamuyu - Cheshskiy Internet: gde zakanchivayetsya svoboda slova I nachinayetsya 'yazyk vrazhdy'?” [Conversation Directly - Czech Internet: Where Freedom of Speech Ends and Starts the "Language of Hatred"?]. Czech Radio 7, Radio Prague. April 1. http://www.radio.cz/ru/rubrika/razgovor/cheshskij-internetgde-zakanchivaetsya-svoboda-slova-i-nachinaetsya-yazyk-vrazhdy.

Wodak, Ruth. 2008. "The Contribution of Critical Linguistics to the Analysis of Discriminatory Prejudices and Stereotypes in the Language of Politics." In Handbook of Communication in the Public Sphere (Handbook of Linguistics, Vol. 4), edited by Ruth Wodak and Veronika Koller, 291-316. Berlin: De Gruyter.

Yevstaf'yeva, Anna. 2009. "Yazyk vrazhdy" v sredstvakh massovoy informatsii: lingvisticheskiy $i$ ekstralingvisticheskiy faktory funktsionirovaniya. [The Language of Hatred in the Media: Linguistic and Extra-Linguistic Factors of Functioning]. Doctoral thesis. Togliatti: TGU. Abstract available at http://www.dslib.net/russkij-jazyk/jazyk-vrazhdy-v-sredstvah-massovoj-informacii-lingvisticheskie-i.html. 